\title{
DESIGNING THE OIL PALM OF THE FUTURE
}

\author{
ZULKIFLI, $Y^{\star}$; NORZIHA, ${ }^{\star}$; NAQIUDDIN, M H*; FADILA, A $M^{\star}$; NOR AZWANI, A B*; SUZANA, ${ }^{\star}$;

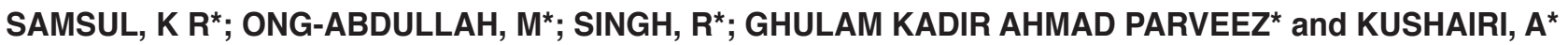

\begin{abstract}
In order to allow for future uninterrupted growth of the oil palm industry in Malaysia, there is a need to increase yield, value-addition of the oil and reduce production costs. The collection and exploitation of germplasm material is considered a major factor in contributing towards a tremendous impact on the Malaysian oil palm industry. Improved oil palm varieties with higher yields, good oil quality, compact in architecture, better adaptation to climate change and higher tolerance to diseases have been prioritised to meet future demands of the oil palm industry. It is only natural that biotechnology and bioinformatics have been identified as the core areas to expedite improvements to achieve these objectives. The use of a combination of conventional and molecular breeding approaches is useful as they open up new avenues for crop improvement and have the potential for producing novel oil palm varieties, in terms of sustainability and its contribution to human well-being.
\end{abstract}

Keywords: oil palm, breeding, planting materials, biotechnology, genomic tools.

Date received: 17 October 2017; Sent for revision: 21 October 2017; Received in final form: 24 Novembar 2017; Accepted: 30 November 2017.

\section{INTRODUCTION}

Originally a minor crop in the 1960s with a yield of $94000 \mathrm{t}$ (Basiron, 2000), palm oil production has steadily increased to become the world's major vegetable oil. The United States Department of Agriculture (USDA) estimates that global palm oil production in 2017 will be 62.88 million tonnes, which is an increase of about 4.08 million tonnes (6.94\%) from 2016 (USDA, 2017). Collectively, Indonesia and Malaysia produce about 57 million tonnes of palm oil, making up over $85 \%$ of global palm oil production. The momentum of high productivity at a lower cost than other vegetable oils, has increased the demand of palm oil especially in India and China (Murphy, 2007). Palm oil is mainly used as an edible product and has good resistance to heat and oxidation, making palm oil an ideal ingredient in frying and dietary component

\footnotetext{
Malaysian Palm Oil Board,

6 Persiaran Institusi, Bandar Baru Bangi,

43000 Kajang, Selangor, Malaysia.

E-mail: zulkifly@mpob.gov.my
}

worldwide. The oil palm has many other uses in the non-food sector, with palm kernel oil mainly used in the oleochemical and animal feed industries. Many biomass-derived products such as plywood and fibreboard, are also produced from oil palm biomass (Suhaily et al., 2012). Oil palm industries produce an enormous quantity of lignocellulosic biomass, a huge source of fibre and cellulosic materials which have potential for further commercialisation. It is projected that conversion of cellulosic fibre into liquid biofuel makes the oil palm a future source of renewable energy which will enhance sustainable development (Basiron, 2007).

The oil palm belongs to the genus Elaeis, which consists of two species, Elaeis guineensis and Elaeis oleifera (Schultes, 1990). The two species are closely related and can be easily inter-crossed to produce an interspecific hybrid (Hardon and Tan, 1969). The major commercially important oil palm is the E. guineensis species. A comprehensive description of oil palm biology is provided by Hartley (1988). Essentially, oil palm has a solitary unbranched stem that is topped by 35-60 pinnate fronds and its height can reach over $20 \mathrm{~m}$. The palm reaches maturity 
when it is about three years old. The crop bears fruits throughout the year and can live up to 200 years, but the productive life of each tree is between 25-30 years (Cheah, 1997). The average annual yield of oil palm plantations is currently around $4 \mathrm{t}$ $\mathrm{ha}^{-1}$. In addition, planting materials producing over 8-10 t ha ${ }^{-1}$ oil have been obtained through selected breeding trials and clonal propagation.

With the projection of population growth touching 9 billion, agricultural products need to increase by $70 \%$ and net exports of oilseeds and vegetable oils are expected to triple by 2050. Despite oil palm's inherent high productivity, its narrow genetic base is a barrier to the industry. The mother palms used were and still is mainly the Deli duras which are direct descendants of the four seedlings brought to Indonesia in 1848 (Rajanaidu et al., 2000). The Malaysian oil palm industry had realised the risk in relying on a limited genetic base and saw the need for an adequate genetic base for effective selection in breeding programmes. Furthermore, selection progress was hampered by the narrow genetic base. A lingering concern was also on the susceptibility of palms to pests and diseases due to its narrow genetic base. The need for genetic variability for future improvements triggered a systematic exploration of oil palm germplasm in Africa and South America spearheaded by MPOB back in the early 1970s. This led to MPOB having now in possession of the world's largest ex situ germplasm collection, comprising collections from 11 African countries for Elaeis guineensis whilst Elaeis oleifera collections were obtained from eight South American sites (Rajanaidu et al., 2013).

The exploitation of germplasm material is beginning to bear its rewards and shows a lot more genetic diversity. Initial collections have provided to date a source of planting materials for important traits such as dwarfness and oil quality (Kushairi et al., 1999a, b). Meanwhile, parental lines of advanced breeding materials are continuously being improved through extensive breeding programmes. Coupled with improving breeding and mass propagation methods to increase yield, the oil palm sector should also focus on higher quality oils and high value niche products for its long-term growth (Murphy, 2007). Stimulating R\&D to generate resistance planting materials to major pests and diseases such as Ganoderma, and improved palm architecture will also have significant impact to the development of new oil palm varieties in the coming decades. In addition, there is also an increasing demand to accelerate oil palm breeding for better adaptation to drought, heat, and other abiotic stresses (Suthashinikisan, 2015). More than a decade ago, the tagline Palm Oil: Nature's Gift to Malaysia and Malaysian Gift to the World which describes the blessings of palm oil to Malaysia, was coined. Though originated from Africa, oil palm flourishes in Malaysia and elsewhere outside its home continent, owing to the favourable tropical climate with good sunshine and rainfall throughout the year. However, weather patterns might change, and to ignore climate change, the oil palm industry would fall into the trap of its own complacency.

Until recently, agricultural scientists, including oil palm breeders and agronomists, have strictly used conventional and hybrid plant breeding to continually improve performance of oil palm productivity. Although results have been outstanding, additional gains in agricultural productivity are demanded at an even faster pace due to continuing changes in agricultural practices and consumer preferences. Modern genomics tools allow substantial knowledge to be attained on the biological traits of a species which can be exploited in improving productivity and obtain better product quality. The whole spectrum of breeding approaches and biotechnology is being deployed to meet these objectives. In this review, we focus on the exploration of oil palm germplasm, traits improvement and how modern genomics tools can contribute to design this remarkable crop.

\section{PLANTING MATERIALS}

\section{Germplasm: Elaeis guineensis}

Oil palm germplasm that exhibits economically important traits is a valuable resource for oil palm improvement. Recognising this, E. guineensis germplasm was collected from Africa to broaden the genetic base of oil palm breeding materials in Malaysia at that time. The first attempt was accomplished in Nigeria in 1973 and evaluated at the MPOB Research Station at Kluang, Johor, Malaysia (Rajanaidu, 1986). Besides Nigeria, prospection was made from other countries in Africa such as Angola, Cameroon, Zaire (now known as the Democratic Republic of Congo), Ghana, Guinea, Gambia, Madagascar, Sierra Leone, Senegal and Tanzania (Rajanaidu and Rao, 1987; Rajanaidu et al., 2013). Extensive screenings should be continuously carried out for those materials collected in order to exploit their genetic potential in oil palm breeding programmes.

Population diversity studies among МРOB oil palm germplasm collection are very crucial for a foundation set of germplasm with minimal repetitive and maximal genetic diversity (Zulkifli, 2012). This core germplasm collection could be established by field and molecular evaluation. Field evaluation includes analysing bunch yield, yield components, vegetative measurement and fatty acid composition (FAC) for each germplasm either using Cluster or Principal Component Analysis which systematically reduce the dimensionality of the data. This method combined with molecular studies 
would be very useful to detect genetic relationships among accessions and subsequently determine the overall degree of polymorphism within germplasm collections. It could be a complete guide to develop strategies to conserve unique genetic sources as best as possible and avoid any redundancy which will not bring informative values to the next generation.

MPOB regularly transfers new technologies (breeding and planting materials) as Planting Series (PS) palms to the industry and to date 14 PS have been transferred. Evaluation of the Nigerian germplasm indicated some interesting attributes such as dwarf (PS1), high iodine value (PS2) and high kernel (PS3) (Rajanaidu et al., 2000). High oleic acid breeding populations (PS12) were also obtained from the Nigerian germplasm (Isa et al., 2006). The Angola palms exhibited large fruit dura (PS6) (Kushairi et al., 2003a) which is similar to Deli duras. Individual Angola palms were also used for a long stalk programme (PS10) to improve efficiency in harvesting (Noh et al., 2005). Besides that, Angola germplasm exhibited wide variability in FAC in their oils compared to those in DxP materials at that time (Noh et al., 2002). Some palms from Nigeria and Madagascar also exhibited iodine value (IV) of more than 60, which is relatively higher than current levels (<50) (Kushairi et al., 2003b).

A study by Marhalil et al. (2015) reported that MPOB germplasm materials assembled from Senegal, Nigeria, Cameroon, Tanzania, Madagascar and Angola had experienced extreme low rainfall. Palms from these collections are potentially useful for the development of drought and heat tolerant planting materials. Some palms from Tanzania are known for thin-shelled tenera (PS5) (Kushairi et al., 2003c) and high bunch index (PS7) (Junaidah et al., 2004). Recently, Fadila et al. (2016) reported that Tanzania, Cameroon, Nigeria and Angola germplasms possessed high bunch index (BI) which is an important trait to consider for the selection of materials towards increasing yields.

Selected palms from the Angola, Cameroon, Nigeria, Tanzania and Zaire germplasm collections produced oils with high vitamin E (PS8) which is measured based on the levels of tocopherols and tocotrienols in palm oil (Kushairi et al., 2004). The mean carotene content (PS11) of E. guineensis collected from the Tanzanian germplasm ranged between 2059 and 2280 ppm (Mohd Din et al., 2006). These palms can be exploited to improve the carotene contents of current planting materials with a reported content of 500 - 700 ppm. Low lipase genotypes (PS13) are also available in MPOB oil palm germplasm materials collected from Cameroon, Guinea and Tanzania (Maizura et al., 2008). Ebongue et al. (2008) reported that low lipase activity among oil palm ripe fruits is desirable to delay free fatty acid (FFA) accumulation which could reduce the quality of palm oil. Genetic materials possessing more than $20 \%$ crude protein in the kernel (PS14) were identified in germplasm collections from Ghana, Cameroon, Gambia, Senegal, Tanzania and Zaire (Noh et al., 2014). The introduction of these materials into commercial populations can improve the protein content in the palm kernel.

Parental lines of advanced breeding materials are continuously being improved through MPOB's extensive breeding programmes. The breeding scheme primarily involves a reciprocal recurrent selection scheme (RRS) which has been adapted by a number of oil palm breeders. In this scheme, the dura and pisifera genotypes are kept as distinctly separate base populations. In the form of hybrids (tenera), the heterosis effect is obtained by crossing origins with complementary characteristics. The performance of inter-origin crosses is attributed to the additive effect of favourable genes combination from the parents. It was reported that the RRS scheme has increased oil yield by almost $18 \%$ per cycle compared to the base population (Rajanaidu et al., 2000). On the other hand, the way to broaden their genetic diversity is through introgression of current materials with selected materials from the germplasm developed by MPOB. In order to achieve the target, various crossings of oil palms with different economically desirable characters were conducted through breeding programmes. Through new combinations, the best materials would be further evaluated and later exploited for future commercial seed production. Rajanaidu et al. (2011) reported that MPOB's latest Nigerian-based planting material has the qualities to develop an ideal palm with balanced bunch number and bunch weight of $15 \times 15 \mathrm{~kg}$. The individual fruit weight is close to $15 \mathrm{~g}$. Musa and Gurmit (2008) introgressed high IV value materials into the present breeding populations have resulted in increased IV $(57-58)$ which is relatively higher than current levels $(<50)$. The oil palm industry in Malaysia should rapidly exploit the genetic potential of germplasm materials to achieve improved productivity and remain competitive and sustainable in the future.

\section{Germplasm: Elaeis oleifera, Interspecific Hybrids and Backcrosses}

Another oil palm species is the Elaeis oleifera, which originates from Central-South America. Elaeis oleifera has brought its own impact to the oil palm industry especially in South-Central America for its contribution in curbing diseases (Corley and Tinker, 2016). A prospection made by MPOB for E. oleifera species covered eight countries viz. Honduras, Brazil, Panama, Colombia, Costa Rica, Suriname, Ecuador and Peru (Rajanaidu, 1994; Rajanaidu and Rao, 1987). Even though it is relatively low in oil yield, its superior unsaturation in oil composition and slow height increment traits to E. guineensis are 
the major areas of interest to oil palm breeders. Apart from that, a high carotene value trait (PS4) was also sourced from this oil palm species (Mohd Din et al., 2002). In spite of the economically beneficial traits of E. oleifera compared to current DxP material, these materials show a low germination rate (below 30\%) which results from a strong dormancy. In fact, this species also tends to have poor fruit sets due to low pollen viability (Norziha et al., 2015).

The present and absent properties of both species has led to the hybridisation of E. oleifera and E. guineensis species, aimed at incorporating desirable qualities from E. oleifera (such as oil quality and palm height) and E. guineensis (such as bunch yield) (Corley and Tinker, 2016). Most research carried out on interspecific hybrids generally revealed intermediate values for oil yield, IV and carotene content (Hardon, 1969; Mohd Din, 2000; Zulkifli et al., 2014). Morphologically, the hybrids tend to have thin shell with a lack of fibre rings (Corley and Tinker, 2016). For the purpose of increasing homozygosity to the desired characteristics, backcrosses to E. guineensis have to be continuously conducted. Being a perennial (at 10 years per generation), it may take quite a long period of time to achieve the final product which would require several generations of backcrosses to the recurrent parent to fix the genes. However, through genomics tools such as quantative trait loci mapping, selection process for the desired product can be accelerated.

\section{Clonal Palms}

High yielding materials have been propagated through the traditional oil palm breeding technique. However, the problem of segregation in seed derived progenies still persists and this technique is tedious and time-consuming. Therefore, oil palm needs to be propagated vegetatively through tissue culture to maximise the potential of selected genotypes. The tissue culture technique has emerged as a feasible and cost-effective tool for developing elite oil palm materials (Sakhanokho and Kelley, 2009). Oil palm tissue culture, which was introduced in 1970s (Jones, 1974), has been widely exercised to fast track breeding programmes. Central to producing elite clones is the availability of high quality ortets. The selection of ortets undergoes stringent criteria such as data collection of up to four years successively for fresh fruit bunch, oil to bunch and a set of data from a minimum of 30 palms per trait. This exercise contributed to a $25 \%$ increase in yield from clonal planting rriaterials in comparison to commercial DxP (Rohani et al., 2000; Tan et al., 2003). In fact, the ortet selection criteria, MS 2099:2008 (SIRIM, 2008), was enacted by Department of Standards, Malaysia as a standard to ensure only superior ramets are produced from high quality ortets.
In terms of clonal performance, Khaw and $\mathrm{Ng}$ (1997) reported that clonal plantlets derived from selected ortets were significantly superior to commercial DxP seedlings. The clones yielded at least 20\% more than DxP standards (Rohani et al., 2000; Corley and Tinker, 2003; Tan et al., 2003). Based on the good attributes that tissue culture has to offer, the interest to go ahead with large scale propagation of oil palm clones is flourishing. This is proven by the growing number of tissue culture laboratories that applied for licenses from MPOB for commercial production. To date, there are currently 14 licensed laboratories producing almost 5 million ramets annually for local supply. Application of tissue culture is not only restricted to multiplying high yielding palms, but also to produce oil palm elite lines that feature other desirable characteristics such as high BI, low height increment, compact, improved tolerance to biotic and abiotic stresses, virescens fruit sets, etc.

\section{TRAITS FOR IMPROVEMENT}

\section{Yield}

Global demand for vegetable oils may reach 240 million tonnes by the year 2050 (Barcelos et al., 2015). Due to expanding populations especially in India and China which make up $37 \%$ of the world population, as well as rising income levels in many developing countries in the 1990s, demand for vegetable oil is steadily increasing (Murphy, 2007). There are four major oilseed crops in the world, i.e. oil palm, soyabean, sunflower and canola (rapeseed). Harvested area of these crops covered a total of 196470 ha with oil palm occupying the least land area of only $9 \%$ of the total land area (Oil World Annual, 2016). Surprisingly, oil palm has the highest productivity, recording 29\% of the total of 203.91 million tonnes oil in 2016, followed by soyabean $(25 \%)$, rapeseed $(12 \%)$ and sunflower $(8 \%)$ (MPOB, 2017a).

The improvement of oil palm yield in Malaysia for the previous half century was attributed to breeding improvement and improved agronomic practices (Davidson, 1993). Corley (2006) estimated that potential oil yields of about $18 \mathrm{t} \mathrm{ha}^{-1}$ with possibilities of oil to bunch $(\mathrm{O} / \mathrm{B})$ at $50 \%$, fruit to bunch $(\mathrm{F} / \mathrm{B})$ at $80 \%$, mesocarp to fruit $(\mathrm{M} / \mathrm{F})$ at $95 \%$ and oil to wet mesocarp $(\mathrm{O} / \mathrm{WM})$ at $65 \%$. However, the average oil yield in Malaysia has been stagnant for more than 20 years. In 2016, the Malaysian palm oil industry produced 17.32 million tonnes of crude palm oil (CPO), $15.91 \mathrm{t} \mathrm{ha}^{-1}$ fresh fruit bunch (FFB) yield with an oil extraction rate (OER) of $20.18 \%$ (MPOB, 2017a). Exclusive usage of Deli dura $\mathrm{x}$ AVROS pisifera (DxP) crosses by most commercial seed producers in this country is starting to limit 
further improvement of commercial planting material (Corley and Tinker, 2016).

Expansion of current plantation area to increase oil palm production by economies of scale is no longer a viable option. The only alternative to boost productivity is by increasing yield and profitability per hectare on existing land. The introduction of exotic germplasm by $\mathrm{MPOB}$ to increase genetic variability was an important step in the oil palm breeding programme. Deli dura x MPOB-Nigeria pisifera crosses (PS1.1) showed a 45\% improvement over the national average in terms of FFB yield (Table 1). Together with dwarf character, these palms should be incorporated as planting material in future replanting programmes. In addition to seedderived palms, planting clonal materials is also promising for yield improvement. Clone P456 and P325 are both high oil yield (OY) candidates, which have performed outstandingly in a few trials (Table 1). These clones also displayed high success rates in tissue culturing and very low mantling rates in the field. Another potential future clone, P126, features a distinctive characteristic, which is short rachis length (RL) of approximately $4.4 \mathrm{~m}$ as compared to 5-6 $\mathrm{m}$ of DxP and other clones. The short RL of this clone makes it suitable for high density (HD) planting (198 palms ha ${ }^{-1}$ for HD as compared to 148 palms ha-1 for normal density). P126 also produces smaller bunches, which is favourable for harvesting. Another clone, P325, showed outstanding O/B and OY rates.

TABLE 1. PERFORMANCE OF MPOB SUPERIOR PLANTING MATERIALS

\begin{tabular}{|c|c|c|c|}
\hline Material & $\begin{array}{c}\text { FFB } \\
\left(t h^{-1} \mathrm{yr}^{-1}\right)\end{array}$ & $\begin{array}{l}\mathrm{O} / \mathrm{B} \\
(\%)\end{array}$ & $\begin{array}{c}\text { OY } \\
\left(\mathrm{t} \mathrm{ha}^{-1} \mathrm{yr}^{-1}\right)\end{array}$ \\
\hline PS 1.1 & 28.6 & 28.0 & $>8.0$ \\
\hline Clone P456 & 33.0 & 29.0 & $8.0-10.0$ \\
\hline Clone P325 & 29.0 & 37.5 & 10.4 \\
\hline Clone P126 (HD) & 32.3 & 28.0 & 9.0 \\
\hline National average* & 18.2 & 20.3 & 3.7 \\
\hline
\end{tabular}

Note: *Average of five years data, from 2012 to 2016. FFB - fresh fruit bunch.

$\mathrm{O} / \mathrm{B}$ - oil to bunch.

OY - oil yield.

On the other hand, efficient management system which includes better harvesting methods, less crop losses due to pests and diseases, less spoilage during transport and storage, and more efficient processing in mills, also play a role in increasing the yields of oil palm (Murphy, 2007).

\section{Adaptation to Climate Change}

Some data on climate change revealed by the National Aeronautics and Space Administration (NASA) were very alarming. Carbon dioxide $\left(\mathrm{CO}_{2}\right)$ levels in the air are currently at their highest in 650000 years, which is more than 406 ppm or an increase of $6 \%$ in the last 10 years (NASA, 2017). Global temperature has increased sharply since 2009 with increases between $0.64^{\circ} \mathrm{C}$ and $0.99^{\circ} \mathrm{C}$ per year (NASA, 2017). Due to global climate change, some effects on the environment had already been observed. As global demand for vegetable oils is increasing, there is a need to address the effects of climate change to oil crops especially in relations to yield or productivity.

A few studies were conducted to recognise the impact of climate change on oil palm growth and yield as well as to strategise research and development in breeding and agronomy for climate change. Development of models to simulate the change in oil palm growth and yield in Malaysia due to climate change have been reported (Christopher, 2015; Nizam et al., 2015; Mohamad Faizal, 2015). These studies were essential to understand oil palm's response to abiotic stresses such as increased levels of $\mathrm{CO}_{2}$ and salinity in water supply.

Some effects of climate change on crops including oil palms and approaches to deal with it in oil palm plantations have been reported by Heslop (2015) and Nuzul (2015). Changes in genetics of crops are needed besides applying adaptation strategies in agricultural practices. Meanwhile, screening of oil palm germplasm for breeding programmes to develop planting material with potentially sustainable yields under extreme weather was initiated by the Malaysian Palm Oil Board (MPOB) and Felda Global Ventures Sdn Bhd (FGV) (Marhalil et al., 2015; Suthashinikisan, 2015). Senegal, Nigeria, Cameroon, Tanzania, Madagascar and Angola germplasms with high bunch number characteristic were identified for the purpose.

\section{Compact Architecture}

One practical approach to increase oil palm yield is by increasing the number of productive oil palms per hectare. Oil palms are commercially planted with a density of 120-150 palms ha-1 (Woittiez et al., 2017). Jusoh et al. (2003) stated that the maximum income could be obtained from a planting density of 148 palms ha-1, contrary to the conventional practice of 136 - 148 palms ha ${ }^{-1}$. However, the planting distance is normally denser on peat soils, at 160 palms ha-1. Palat et al. (2012) reported that an effective strategy for yield maximisation is high-density planting followed by selective thinning at 8 - 9 years after planting. Some early signs of depressive effect on yields were found for high planting densities (180

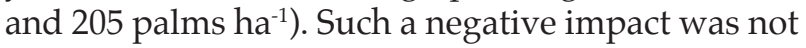
severe enough to counteract the effects of the higher number of palms per hectare (Bonneau et al., 2014). Recently, Breure (2017) reported that optimal density 
can be derived from the leaf area index (LAI). The LAI value at mature crown size or at about 10 years after planting would give the most realistic estimate of optimal planting density. For maximum yield per hectare, the optimal LAI was assumed to lie between 5.5 and 6 (Breure, 2010). Besides planting density, oil palms with lower height increment (HTi) found in some Nigerian-derived progenies are amenable to easier harvesting and mechanisation (Junaidah et al., 2008; Isa et al., 2008). Based on the extensive screening of MPOB germplasm, breeding for shorter RL and lower HTi will open up the possibility of developing compact palms suitable for higher density planting and subsequently increase oil palm yields. Numerous studies on the development of compact palms have been reported. Guzman and Peralta (2010) reported that six compact clones with excellent agronomic characteristics such as short leaves and stems, precocious and high yielding, have been selected for commercial production. Standard E. guineensis lines such as Deli, Ghana and Nigeria crossed with COMPACT palms produced leaves of $6.6-6.9 \mathrm{~m}$ long and can be planted at a density of 170 palms ha ${ }^{-1}$ which is still higher than the industry standard of 138-143 palms ha ${ }^{-1}$ (Corley and Tinker, 2003). Current research in MPOB reported that P126 palms exhibited short $\mathrm{RL}$ of about $4.4 \mathrm{~m}$ on average which were possible for use in high density plantings (Zamzuri, 2011). Recently, Norziha et al. (2017) reported that MPOBTanzania germplasm showed good potential as breeding material for compactness with reasonable yields and would be introgressed into advanced breeding populations to generate future valueadded planting materials in Malaysia.

\section{Oil Quality}

The quality of oil is a reflection of its FAC and this determines its functionality. Palm oil is about $50 \%$ saturated fat and equal in monounsaturated fats. This profile restricts the potential uses of palm oil beyond a relatively basic commodity function for either edible or oleochemical markets (Murphy, 2007). It is envisaged that modifying or changing the FAC of palm oil could improve or extend its usage. Particularly of interest is increasing the proportion of monounsaturated fatty acids (particularly oleic acid) and reducing the content of saturated fatty acids (e.g. palmitic acid). Such oil has the potential to open up markets for oil palm in the liquid oil sector and would compete more effectively with other oil crops such as soyabean, rapeseed and sunflower. Apart from the FAC, improving the IV, which is a measure of oil unsaturation, and carotene content are also sought after. Oil high in carotene is desirable as there is a growing demand for natural sources of carotene for food colouring (Corley and Stratford, 1998).
In terms of oil quality, E. oleifera has higher levels of oleic and linoleic acids and its IV can reach up to more than 90 (Rajanaidu et al., 2000), thus this species should be examined and assessed effectively. In E. guineensis, several promising lines of germplasm with 50\%-60\% oleic acid have already been identified and show great promise to produce a combination of altered fatty acid profile and high OY with existing commercial lines (Isa et al., 2006). Meanwhile, several varieties of oil palm germplasm from both oil palm species have been identified with high carotene content which has stimulated great interest in the potential of palm oil in the lucrative health foods market (Rajanaidu et al., 1999; Mohd Din et al., 2006). In recent years, a few molecularbased studies have identified quantitative trait loci linked to FAC in oil palm (Singh et al., 2009; Montoya et al., 2013; Ting et al., 2016). This is in view to understand the molecular mechanisms associated with the inheritance of higher unsaturated oil. Breeders and researchers should take multipronged approaches to address this challenge using conventional and molecular breeding strategies to achieve the prospects for higher oil quality.

\section{Tolerance to Diseases}

Basal Stem Rot (BSR), caused by a white rot fungus known as Ganoderma boninense, is a major threat to the oil palm industry (Cooper et al., 2011), especially in South-east Asia. This currently incurable disease has caused major economic losses to Malaysia and Indonesia, the two largest palm oil producing countries. Malaysia alone recorded approximately USD 500 million of yearly losses (Assis et al., 2016). Far from solving this very problem, experts predicted that the infected area would expand to 443430 ha in 2020 (Roslan and Idris, 2012) or approximately $8 \%$ of the current total oil palm plantation area in Malaysia. Application of chemical and biological agents to overcome the disease has been implemented but the results are less than satisfactory (Shamala, 2013). To address this crucial issue, MPOB together with industry members had ranked Ganoderma resistance as one of the top priorities for oil palm improvement in Malaysia through breeding programmes (Basri, 2003). Idris et al. (2004), who conducted seedling inoculation screenings from multi-parental oil palm populations in search for genetic resistance against Ganoderma, found that DxP Zaire $x$ Cameroon progenies displayed partial resistance. This line of study provides useful information on the genetic diversity of multi-parental populations and is important for a rational use of genetic resources. Moving forward, plant breeders need to include analysis of genetic variation of potential and elite planting materials for a more holistic understanding. It will also help in monitoring germplasms as well as predicting the 
potential of Ganoderma tolerance trait. In addition, to increase precision in selection of tolerant planting material, a combination of molecular marker technologies with advanced quantative trait loci mapping technique may provide a powerful tool to unravel candidate genes controlling qualitative disease tolerance, not only towards Ganoderma, but also for other oil palm associated diseases including Fusarium wilt, Coconut Cadang-Cadang Viroid (CCCVd), bud rot, etc.

\section{TECHNOLOGIES FOR IMPROVEMENT}

\section{Genome Sequencing and Molecular Markers}

Conventional oil palm breeding is influenced by environmental factors, phenotyping accuracy and requires long generation cycles (10-12 years). Efforts to increase palm oil yield and other traits of interests have been initiated via various research strategies involving biotechnological techniques. In 2013, MPOB with international collaborators reported on the 1.8-gigabase $(\mathrm{Gb})$ genome sequence of Elaeis guineensis (Singh et al., 2013a). The oil palm genome sequence greatly helped in mining genes of interest controlling important traits that were previously targeted conventionally by oil palm breeders. Meanwhile, molecular markers are rapidly evolving and have been improved by far with new technologies and knowledge in the oil palm genomics field. The ability to link specific markers with useful traits via molecular method enables marker-assisted-selection (MAS) which allows selection based on DNA information is more reliable in speeding up genetic improvement compared to conventional breeding. In oil palm research, different types of markers were developed and used in different areas of studies such as genetic diversity (Zulkifli et al., 2012; Zaki et al., 2012; Okoye et al., 2016), DNA fingerprinting (Lim and Rao, 2005), quantitative trait loci mapping (Mayes et al., 1997; Singh et al., 2009) and association mapping (AM) (Chuenporm and Volakert, 2017). A modern molecular marker, single nucleotide polymorphism (SNP), offers several advantages over classical markers in terms of its abundance, genetic stability, and it is also amenable for high-throughput automated analysis (Vignal et al., 2002). It is proposed that this marker should be extensively used for oil palm improvement in future. The complete oil palm genome sequence and high density SNP array (92 459 SNP) are now available at MPOB.

The SHELL gene, which has been successfully mapped and identified, controls a monogenic trait responsible for the dura, pisifera and tenera fruit forms in E. guineensis (Singh et al., 2013b). The SureSawit SHELL Gel Kit was then developed and commercialised for early screening of different fruit forms at the nursery stage, prior to field planting. It beneficially serves as quality control tool to eliminate dura contamination in commercial planting materials. Another assay, the SureSawit VIR kit, allows planters to select the more easily identified mature virescens (Vir) palms instead of planting nigrescens (Nig), thus helping to reduce loose fruits and optimal oil content could be harvested. Oil palm production can then be increased by close to one-third without the burden of expanding oil palm land area. With the available oil palm genome sequence, it is foreseen to help oil palm researchers across the world in creating sustainable oil palms for the future.

Linkage mapping has been a foundation in the genetic analyses of quantitative trait loci in plants. Quantative trait loci mapping in oil palm was constructed using various marker technologies to identify quantative trait loci associated with desired traits such as yield (Rance et al., 2001), height (Pootakham et al., 2015), oil composition (Singh et al., 2009; Montoya et al., 2013; Ting et al., 2016) and also for callogenesis and embryogenesis in oil palm tissue culture (Low et al., 2008). Searching for more important complicated traits such as yield and Ganoderma tolerance using quantative trait loci mapping is now of greater concern for MPOB to ensure the sustainability of the Malaysian palm oil industry.

Linkage disequilibrium (LD) mapping or association mapping (AM) has been used to find linkages among independent populations (SotoCerda and Cloutier, 2012). The mapping resolution will be higher with unlimited number of alleles, thus marker trait-association could be discovered more efficiently (Flint-Garcia et al., 2013). Recently, SNP markers with significant linkages to oil palm yield, fruit to bunch (FTB) and oil to dry mesocarp (OTDM) have been identified (Chuenporm and Volakert, 2017). AM is suitable for the analysis of the MPOB germplasm collection of E. guineensis and E. oleifera previously reported to possess high genetic variability (Ong et al., 2015). Thousands of materials from this collection could be extensively screened and outstanding palms with interesting traits such as low height, thin shell, long stalk, high BI, vitamin $\mathrm{E}$ and carotene can be potentially identified.

Two new approaches, namely genomic wide association studies (GWAS) and genomic selection (GS), have emerged as more effective selection tools. In oil palm, GWAS has been implemented to increase selection gain per unit time and cost with small populations (Wong and Bernardo, 2008), predict GS accuracy (Cros et al., 2015), select higher oil content (Bai et al., 2017) and OTDM (Teh et al., 2016). GS is a method broaden from MAS but uses a wide coverage of markers in the genome so that breeding values of complex traits can be identified precisely (Goddard and Hayes, 
2007) without needing accurate knowledge of their specific location. It allows the early selection of elite materials and maximises genetic gain per unit time. In oil palm and other perennial crops, increasing genetic gain requires adequate GS accuracy in selecting candidates to shorten breeding cycles and increase selection intensity (Cros et al., 2015). GS is not yet widely implemented by oil palm genome researchers, hence the information on the reliability of GS for oil palm is still limited. GWAS and GS have now been seriously initiated and will hopefully accelerate genetic improvement of current materials via genomics-guided breeding.

\section{Plant Variety Protection (PVP) and DNA Fingerprinting}

Breeding of new plant varieties requires investment of time, labour and money. It may take many years of research and development to release a new variety for commercial planting. Once a new variety is released, there is a high risk of it being reproduced by others, thus depriving its breeder/ developer the opportunity to acquire his rightful profit. The New Plant Variety Protection Act 2004 by the Department of Agriculture (DOA), Malaysia was enforced with the objectives to provide rights, acknowledgement and protection to those bringing in new plant varieties. Further investment and development of more new plant varieties may also be motivated due to this Act (Laws of Malaysia, 2004). Based on this Act, Oil Palm Test Guidelines (OPTG) for distinctness, uniformity and stability of new palm varieties has been drawn up (DOA, 2010). These test guidelines can be applied to all varieties of E. guineensis Jacq. and its derivatives including interspecific hybrids (E. guineensis x E. oleifera), their reciprocal crosses and backcrosses. Phenotypic traits such as RL, petiole cross-sectional area, bunch shape, fruit type, fruit shape and mean fruit weight are recognised descriptors to differentiate each variety. DNA-based fingerprinting could be the best option to distinguish at a molecular level the varieties for patent protection as well as registration under the New Plant Variety Protection.

Legitimacy confirmation is important in oil palm breeding programmes as controlled pollination, seed germination, nursery and field planting are labour intensive and tedious which may lead to pollination contamination by stray pollen or seedling mix-ups, hence some or all of the progeny would be illegitimate. With the deployment of DNA fingerprinting techniques, quality control testing has been accelerated to as early as the seed stage which has been implemented by Sime Darby Plantation (Arutchelvam et al., 2017). FGV has a well-developed oil palm DNA fingerprinting method and their current focus is to assist breeders in improving the next generation of pisifera descendants by ensuring that the selected palms from existing pisifera descendants are legitimate (Siti Hawa et al., 2015). Using DNA fingerprinting, Rajinder et al. (2007) reported SSR markers can be used for clonal identification, monitoring line uniformity between and within clones and detecting culture mix-up.

\section{Phenomics and Phenotyping}

Phenomics is defined as systematic high throughput phenotype studies on a genome widescale (Bilder et al., 2009). It is a new experimental approach developed to relate genomics features to phenotype with the aim to link to phenotypic traits (Hancock, 2014). This technology accelerates progress in understanding gene function and environmental responses. Plant phenomics study on plant growth, performance and composition for valuable traits will enable breeders to develop new oil palm varieties to support future production. Phenomics also makes it possible to trace traits and facilitate the introgression of novel variation from wild germplasm (Tester and Langridge, 2010).

Phenotyping work is widely recognised as the most laborious and technically challenging part. For a germplasm to be screened for a valuable agricultural trait, replicated trials are necessary across multiple environments. Furthermore, this phenotyping work needs to be done precisely especially when the phenotypic data will be used in molecular research. The phenotyping bottleneck can now be addressed by combining novel technologies such as noninvasive imaging, spectroscopy, image analysis, robotics and high-performance computing (Furbank and Tester, 2011). As a result, field evaluation of palms performance is much faster, more dynamic and reliable.

\section{Bioinformatics and Database}

Bioinformatics has been described as new discipline that involves the biologist, mathematicians and computer scientist in efforts to interpret a large scale of data generated by genome sequencing and other 'omic technologies (Kanehisa and Bork, 2013; Murphy, 2014). In the past decades, bioinformatics has become critical part of genomic research and functional genomic technologies. The advancement of bioinformatics tools has brought about a deeper understanding of genome architecture and accelerated biotechnological research innovations and huge data interpretation (MPOB, 2017b). The recent leap of sequencing projects has led to a huge amount of DNA that needs to be analysed and assembled. Genetic maps, genotypes or expression information must be analysed to obtain relevant biological information. In oil palm, the Genomsawit web portal (Rosli et al., 2014) and MYPalmViewer 
genome browser (Low et al., 2015) were developed by $\mathrm{MPOB}$ as resources to identify relevant information of the genome data. Efforts will also be focused on improving annotation and identification of marker-trait association to support molecularbased research.

The process of collecting accurate data in field works is tedious and time-consuming. To meet research requirements, data must be presented in the most structured, systematic and scientific way. In MPOB, a system called the MPOB Breeding Information System (MPOB-BIS ${ }^{\mathrm{TM}}$ ) has been developed as a significant tool in accumulating field data (Mohd Din et al., 2012). This user-friendly conceptual system has enabled all information related to research data to be managed and implemented with the latest use of information technology in a more systematic manner. The system also allows data to be interpreted and statistically analysed more effectively. This module has also significantly reduced labour and material costs by reducing the time needed for data checking and analysis.

\section{Haploid Technology}

Current oil palm seeds used for commercial plantings are produced from individual parents selected from genetically heterogeneous populations of non-homozygous palms. Thus, seeds produced from oil palm crosses are not genetically uniform. This genetic variation impedes the oil palm industry from selecting specific genotypes for high yield or other desirable traits. With doubled haploid technology, homozygosity is achieved in one generation. Thus, the oil palm breeder can eliminate the numerous cycles of inbreeding which is usually necessary to achieve practical levels of homozygosity by conventional methods. Kumar and Sparjanbabu (2013) reported various developments in haploid breeding with respect to economically important palm species. Haploids exist at low frequency and can be obtained naturally or spontaneously. The first report of doubled haploid production in oil palm via haploid tissue culture was published by Sumatra Bioscience (Iswandar et al., 2010). A breakthrough in oil palm research has been the detection of naturally occurring haploids and doubled haploids which can be exploited immediately in $\mathrm{F}^{1}$ hybrid breeding (Dunwell et al., 2010). The current research in MPOB involves screening of culled oil palm germinated seeds obtained from germplasms as well as advanced breeding populations. The germinated seeds were then characterised based on their abnormalities, prior to planting and followed by flow cytometry analysis. High throughput flow cytometry is a useful method to screen naturally occurring haploids in abnormal oil palm germinated seeds (Wan Ibrahim et al., 2011). Genotyping doubled-haploids using
SNP arrays could enable reverse breeding of oil palms (Ting et al., 2014). In future, haploid research will have an enormous impact on conventional oil palm breeding because it can significantly reduce the time taken to develop a new planting material compared with traditional breeding techniques. Furthermore, it can also be used to create palms with novel characteristics.

\section{Epigenetics}

In addition to genomics research, epigenetic information may also provide opportunity for traits enhancement. However, this area of research is relatively less explored compared to genomic studies. Epigenetic occurrences such as transgenic silencing, paramutation, imprinting and DNA methylation are quite common phenomena in plants and potentially offer molecular resources for targeted crop improvement (Springer and Schmitz, 2017). A recent breakthrough by exploiting epigenetic information has successfully unravelled the cause of floral abnormality or known as 'mantling' of clonal oil palm planting materials. Changes in DNA methylation of the 'Karma' retro-element, located within an intron of EgDEF1, was found to be involved in defining the mantled phenotype (OngAbdullah et al., 2015). Subsequently, a KARMA screening assay was commercially developed to screen nursery plantlets (Ong-Abdullah et al., 2016). This would allow assessment of the mantling risk and early culling of plants to circumvent economic and time losses involved in the event of planting mantled palms. Therefore, incorporating epigenome profiling and engineering into oil palm research may complete the missing piece of the puzzle towards designing the oil palm of the future.

\section{Genome Editing}

Genetically modified (GM) crop plants through conventional breeding have long been utilised for the objectives of improving oil yield and quality. Over the years, a new approach called genome editing (GE) has emerged that enables researchers to precisely make improvements by manipulating targeted genes in a diverse range of cell types and organisms (Sattar et al., 2017). GE enables DNA to be either inserted, deleted or replaced in the genome using engineered nucleases, or 'molecular scissors'. There are few types of these nucleases with their respective pros and cons compared to each other. The latest contemporary clustered regularly interspaced short palindromic repeats (CRISPR) along with CRISPR-associated protein 9 (Cas9) provides several benefits over the like zinc finger nucleases (ZNF) and transcription activator-like effector nucleases (TALEN). Using GE technology, the scope of traits that could be modified will be expanded and the 
identification of key genes that regulate complex traits by genomics and omic technologies will be much easier. There is an optimistic prediction that GM crops will capture people's attention and commercial GM might be released before the end of 2020s (Soh et al., 2017). GE studies in oil palm is now at its infancy and is progressing with the aim to fully understand the prospects of transgenic oil palm locally and globally.

\section{CONCLUSION}

Malaysia's rich oil palm germplasm resource coupled with the advent of biotechnology has tremendously accelerated oil palm research. The narrowness of the active gene pool was recognised as one of the major setbacks to a successful and rapid selection progress in oil palm breeding. It is important to exploit the oil palm germplasm, because even though oil palm is a multi-billion dollar industry, the whole industry is surprisingly based on an extremely narrow genetic base. Dealing with vast oil palm populations, from wild germplasms to breeding lines to intra- and interspecific hybrid programmes and eventually to advanced planting materials, the MPOB-BIS ${ }^{\mathrm{TM}}$ was designed to efficiently handle the massive breeding $R \& D$ data and to enable future links with other databases such as tissue culture and the omics-es. The research knowledge, utilisation and genetic materials exchange on the germplasm collections are already available to other countries. As we embrace the $4^{\text {th }}$ Industrial Revolution, these links are becoming more important and the lines dividing physical, digital and biological spheres are getting blurred as we move towards the era of precision agriculture, especially in molecular precision farming.

Synergistic collaboration between MPOB with local and foreign research groups have culminated in numerous publications, thereby enhancing the international image of oil palm science. Acknowledging the potential gap between discoveries and practical applications, early research has been focused on simple traits such as in the formation of shell in oil palm fruits and fruit colour as well as in addressing pertinent issues in the industry for example abnormality in oil palm clones. These findings have since been developed into ready-to-use technologies; however there has been a snag in their adoption. While improvements in agricultural biotechnology certainly hold considerable promises, significant implementation gaps that exist may reduce their impact. It is our hope that as the oil palm industry in Malaysia celebrates its $100^{\text {th }}$ anniversary; it will break away from traditions and trail blaze into the future as innovators of the industry.

\section{ACKNOWLEDGEMENT}

The authors would like to thank the Director-General of MPOB for permission to publish this article.

\section{REFERENCES}

ARUTCHELVAM, B; HAFIZA, A; SUKGANAH, A; TEH, C K; MOHAIMI, M and DAVID, R A (2017). Quality assurance for oil palm seed production in Sime Darby Plantation. Proc. of the $12^{\text {th }}$ Malaysia International Genetics Congress. p. 66.

ASSIS, K; CHONG, K P; IDRIS, A F and HO, C M (2016). Economic loss due to Ganoderma disease in oil palm. International J. Social, Behavioral, Educational, Economic, Business and Industrial Engineering, 10: 6315.

BAI, B; WANG, L; LEE, M; ZHANG, Y; RAHMADSYAH; ALFIKO, Y, QING YE, B; WAN, Z Y; LIM, C L; SUWANTO, A; CHUA, N-H and YUEM, G H (2017). Genome-wide identification of markers for selecting higher oil content in oil palm. BMC Plant Biol., 17: 93.

BARCELOS, E; DE ALMEIDA RIOS, S; CUNHA, R N V; LOPES, R; MOTOIKE, S Y; BABIYCHUK, E; SKIRYCZ, A and KUSHNIR, S (2015). Oil palm natural diversity and the potential for yield improvement. Front. Plant Sci., 6: 190.

BASIRON, Y (2000). Techno-economic aspects of research and development in the Malaysian oil palm industry. Advances in Oil Palm Research (Yusof Basiron; Jalani, B S and Chan, K W eds.). MPOB, Bangi. p. 1-18.

BASIRON, Y (2007). Palm oil production through sustainable plantations. Euro J. Lipid Sci. Tech., 109: 289-295.

BASRI, M W (2003). Prioritizing future products for the oil palm industry. Brainstorming session for strategic plan to hasten breeding for 10 priority traits. Putrajaya, Malaysia.

BILDER, R M; SABB, F W; CANNON, $\mathrm{T}$ D; LONDON, E D; JENTSCH, J D; PARKER, D S; POLDRACK, R A; EVANS, C and FREIMER, N B (2009). Phenomics: the systematic study of phenotypes on a genome-wide scale. Neuroscience, 164 (1): 30-42.

BONNEAU, X; VANDESSEL, P; BUABENG, M and ERHAHUYI, C (2014). Early impact of oil palm planting density on vegetative and oil yield variables in West Africa. OCL, 21(4): A401. 
BREURE, C J (2010). Rate of leaf expansion: a criterion for identifying oil palm (Elaeis guineensis Jacq.) types suitable for planting at high densities. Wageningen J. Life Sciences: 141-147.

BREURE, C J (2017). Statistical guidelines for comparing commercial oil palm varieties. J. Oil Palm Res. Vol. 29 Vol. 29(1): 11-22.

CHEAH, S C (1997). The biotechnology of oil palm. Abstracts of the Agricultural Biotechnology for Sustainable Productivity (ABSP) Global Conference. Asilomar Conference Center, Pacific Grove, California, USA.

CHRISTOPHER, T B S (2015). Response of oil palm due to climate change: simulations and challenges. International Seminar on Gearing Oil Palm Breeding and Agronomy for Climate Change. Kuala Lumpur, Malaysia. p. 17-24.

CHUENPORM, N and VOLKAERT, H (2017). Association mapping identifies markers linked with yield traits in an oil palm breeding population. Thai J Sci Tech, 6(4): 392-405.

COOPER, R M; FLOOD, J and REES, R W (2011). Ganoderma boninense in oil palm plantations: current thinking on epidemiology, resistance and pathology. The Planter, 87: 515-26.

CORLEY, R H V and STRATFORD, R (1998). Biotechnology and oil palm: opportunities and future impact. Proc. of the 1998 International Oil Palm Congress- Commodity of the Past, Today and Future (A Jatmika ed.). Indonesian Oil Palm Research Institute, Medan, Indonesia. p. 80-91.

CORLEY, R H V and TINKER, P B (2003). The Oil Palm. Oxford: John Wiley \& Sons.

CORLEY, R H V (2006). Potential yield of oil palm - an update. Int. Soc. Oil Palm Breeders Symposium. Phuket, Thailand.

CORLEY, R H V and TINKER, P B (2016). The Oil Palm. Fifth edition. Blackwell Science Ltd. p. 52.

CROS, D; DENIS, M; SÁNCHEZ, L; COCHARD, B; FLORI, A; DURAND-GASSELIN, T; NOUY, B; OMORÉ, A; POMIÉS, V; RIOU, V; SURYANA, E and BOUVET, J M (2015). Genomic selection prediction accuracy in a perennial crop: case study of oil palm (Elaeis guineensis Jacq.). Theor Appl Genet, 128: 397410.

DAVIDSON, L (1993). Management for efficient, cost-effective and productive oil palm plantations. Proc. of the 1991 PORIM International Oil Palm
Conference - Agriculture (Basiron, Y et al. eds.). PORIM, Bangi. p. 153-167,

DOA (2010). Guidelines for the Conduct of Tests for Distinctness, Uniformity and Stability. Oil Palm Elaeis guineensis Jacq. and its Derivatives. Department of Agriculture, Malaysia.

DUNWELL, J M; WILKINSON, M J; NELSON, S; SRI W S; ANDREW, C; MIENANTI, D; ALFIKO, Y; CROXFORD, A E; FORD, C S; FORSTER, B P and CALIGARI, P D S (2010). Production of haploids and doubled haploids in oil palm. BMC Plant Biol., 10: 218 .

EBONGUE, G F N; KOONA, P; NOUY, B; ZOK, S; CARRIÈRE, F and ZOLLO, P H (2008). Identification of oil palm breeding lines producing oils with low acid values. Eur. J. Lipid Sci. Technol., 110: 505-509.

FADILA, A M; NORZIHA, A; MOHD DIN, A; RAJANAIDU, $\mathrm{N}$ and KUSHAIRI, A (2016). Evaluation of bunch index in MPOB oil palm (Elaeis guineensis Jacq.) germplasm collection. J. Oil Palm Res.Vol. 28: 442- 451.

FLINT-GARCIA, S; THORNSBERRY, J and BUCKLER, E (2003). Structure of linkage disequilibrium in plants. Ann Rev Plant Biol, 54: 357374.

FURBANK, R T and TESTER, M (2011). Phenomics technologies to relieve the phenotyping bottleneck. Trends Plant Sci., 16: 635-644.

GODDARD, M E and HAYES, B J (2007). Genomic selection. J Anim Breed Genet, 124(6): 323-330.

GUZMAN, N and PERALTA, F (2010). Advances in tissue culture propagation of compact oil palm clones in Costa Rica. Proc. of the Advances in Oil Palm Tissue Culture. Yogyakarta, Indonesia. p. 59-66.

HANCOCK, J M (2014). Introduction to phenomics. Phenomics. ORC Press, US. p. 2.

HARDON, J J and TAN, G Y (1969). Interspecific hybrids in the genus Elaeis I and II. Euphytica, 18: 372-380.

HARTLEY, C W S (1988). The botany of oil palm. The Oil Palm. Third edition. Longman, London. p. 47-94.

HESLOP, H (2015). Crops, climate change and superdomestication. Proc. of the International Seminar on Gearing Oil Palm Breeding and Agronomy for Climate Change. Kuala Lumpur, Malaysia. p. 3. 
IDRIS, A; KUSHAIRI, A; ISMAIL, S and ARIFFIN, D (2004). Selection for partial resistance in oil palm progenies to Ganoderma basal stem rot. J. Oil Palm Res. Vol. 16: 12-18.

ISA, Z A; MOHD DIN, A; MAIZURA, I; NOH A; KUSHAIRI, A and RAJANAIDU, N (2006). PS12: Breeding population for high oleic acid palm oil. MPOB Information Series No. 313. MPOB, Bangi, Malaysia.

ISA, Z A; ONG, K P; NORASYIKIN, I and SUBOH, O (2008). Performance of MPOB-Nigerian population 12 - an update. Proc. of the $3^{\text {rd }}$ Seminar on Performance of MPOB PS1 and PS2 Materials and Elite Germplasm. MPOB, Bangi. p. 139-149.

ISWANDAR, H E; DUNWELL, J M; FORSTER, B P; NELSON, S P C. and CALIGARI, P D S (2010). Doubled haploid ramets via embryogenesis of haploid tissue cultures. Proc. of the Advances in Oil Palm Tissue Culture. p. 100-104.

JONES, L H (1974). Propagation of clonal oil palms by tissue culture. Oil Palm News, 17: 1-8.

JUNAIDAH, J; KUSHAIRI, A; ISA, Z A; MOHD DIN, A; NOH, A and RAJANAIDU, N (2004) PS7: high bunch index breeding population. $M P O B$ Information Series No. 221. MPOB, Bangi.

JUNAIDAH, J; CHIN, C W; RAFII, M Y and SYUHADA, W H (2008). Performance and utilization of MPOB-Nigerian oil palm materials in FELDA. Proc. of the $3^{\text {rd }}$ Seminar on Performance of MPOB PS1 and PS2 Materials and Elite Germplasm, MPOB, Bangi. p. 73-90.

JUSOH, L; MOHD NOOR, M; MOHD TAYEB, D and KUSHAIRI, A (2003). Economics of higher planting in oil palm plantations. MPOB, Bangi. p. 32-39.

KANEHISA, M and BORK, P (2013). Bioinformatics in the post-sequence era. Nature Genetic Resource Supplement, 33: 305-310.

KHAW, C H and NG, S K (1997). Performance of commercial scale clonal oil palm (Elaeis guineensis Jacq.) planting in Malaysia. Proc. of the International Society of Horticultural Science Symposium. Brisbane, Australia. p. 8.

KUMAR, S K and SPARJANBABU, D S (2013). Haploid breeding in palms - a brief review. Adv Crop Sci Tech, 1: 113.

KUSHAIRI, A; RAJANAIDU, N and JALANI, B S (1999a). PORIM Series 2. PORIM Information Series No. 101. PORIM, Bangi.
KUSHAIRI, A; RAJANAIDU, N; JALANI, B S and ISA, Z A (1999b). PORIM Series 1- PORIM elite oil palm planting materials. PORIM Information Series No. 100. PORIM, Bangi.

KUSHAIRI, A; RAJANAIDU, N; MOHD DIN, A; ISA, Z A; NOH, A and JUNAIDAH, J (2003a). PS6: Breeding populations selected for large fruit duras. MPOB Information Series, No. 184. MPOB, Bangi.

KUSHAIRI, A; RAJANAIDU, N and MOHD DIN, A (2003b). Mining the germplasm. Proc. of the ISOPB Seminar on the Progress of Oil Palm Breeding and Selection, Medan, Sumatra, Indonesia.

KUSHAIRI, A; RAJANAIDU, N; MOHD DIN, A; ISA, Z A; NOH, A and JUNAIDAH, J (2003c). PS5: Breeding populations selected for thin shell teneras. MPOB Information Series 183. MPOB, Bangi, Selangor.

KUSHAIRI, A; RAJANAIDU, N; SUNDRAM, K and MAIZURA, I (2004). PS8: vitamin E breeding population. MPOB Information Series No. 222. MPOB, Bangi.

LAWS OF MALAYSIA (2004). Protection of New Plant Varieties Act 2004 (Act 634). PNMB.

LIM, C C and RAO, V (2005). DNA fingerprinting of oil palm - choice of issues. J. Oil Palm Res. Vol. 17: 136-144.

LOW, E T L; HALIMAH, A; BOON, S H; ELYANA, M S; TANC, Y and OOI, L C L (2008). Oil palm (Elaeis guineensis Jacq.) tissue culture ESTs: identifying genes associated with callogenesis and embryogenesis. BMC Plant Biol., 8: 62.

LOW, L E T; MOHD AMIN, A H; ROZANA, R; CHAN K L; NORAZAH, A; JAYANTI, N; NIK SHAZANA, N M; NADZIRAH, A; AHMAD SADIQ, A B; FAIZUN, K; SINGH, R; ONGABDULLAH, $\mathrm{M}$ and SAMBANTHAMURTHI, $\mathrm{R}$ (2015). MyPalmViewer: Oil palm genome browser. MPOB Information Series No. 141. MPOB, Bangi.

MAIZURA, I; KUSHAIRI, A; NOHD DIN, A; $\mathrm{NOH}, \mathrm{A}$; MARHALIL, $\mathrm{M}$; WONG, $\mathrm{Y} \mathrm{T}$ and SAMBANTHAMURTHI, R (2008). PS13: Breeding populations selected for low lipase. $M P O B$ Information Series No. 400. MPOB, Bangi.

MARHALIL, M; MOHD DIN, A; RAJANAIDU, N and KUSHAIRI, A (2015). Utilization of MPOB oil palm germplasm for climate change. Proc. of the International Seminar on Gearing Oil Palm Breeding and Agronomy for Climate Change, Kuala Lumpur, Malaysia, p. 7. 
MAYES, S; JACK, P L; MARSHALL, D F and CORLEY, R H V (1997). Construction of a RFLP genetic linkage map for oil palm (Elaeis guineensis Jacq.) Genome, 40: 116-222.

MOHAMAD FAIZAL, $\mathrm{T} \mathrm{B}$; ROSLAN, $\mathrm{H}$ and SAMSUDIN, T (2015). Determination of groundwater salinity for water supply and agricultural activity at coastal area using resistivitychemistry integrated methods. International Seminar on Gearing Oil Palm Breeding and Agronomy for Climate Change. Kuala Lumpur, Malaysia. p. 26-54.

MOHD DIN, A (2000). Genetic Variation for Yield, Bunch Component and Vegetative Traits in Oil Palm (Elaeis oleifera) and Interspecific Hybrids. Ph.D thesis. Universiti Kebangsaan Malaysia, Bangi.

MOHD DIN, A; RAJANAIDU, N; KUSHAIRI, A; MOHD RAFII, Y; MOHD ISA, Z A and $\mathrm{NOH}$, A (2002). PS4: High carotene E. oleifera planting materials. $\mathrm{MPOB}$ Information Series No. 137. MPOB, Bangi.

MOHD DIN, A; NOH, A; MOHD ISA, Z A; MAIZURA, I; KUSHAIRI, A and RAJANAIDU, N (2006). PS11: High carotene E. guineensis breeding population. MPOB Information Series No. 312. $\mathrm{MPOB}$, Bangi.

MOHD DIN, A; RAJANAIDU, N; KUSHAIRI, A and ZAHARAH, R (2012). Breeding information system (MPOB-BIS). MPOB Information Series No. 512. MPOB, Bangi.

MONTOYA, C; LOPES, R; FLORI, A; CROS, D; CUELLAR, T; SUMMO, M; ESPOUT, S; RIVALLAN, R; RISTERUCCI, A M; BITTENCOURT, D; ZAMBRANO, J R; ALARCÓN, W H; VILLENEUVE, P; PINA, M; NOUY, B; AMBLADR, P; RITTER, E; LEROY, T and BILLOTTE, N (2013). Quantitative trait loci (QTLs) analysis of palm oil fatty acid composition in an interspecific pseudo-backcross from Elaeis oleifera (H B K) Cortés and oil palm (Elaeis guineensis Jacq.). Tree Genet Genomes, 9(5): 1207-1225.

MPOB (2017a). Malaysian oil palm industry performance 2016 and prospects for 2017. http: / / www.mpob.gov.my / images / stories / pdf/2017/2017_Dr.KushairiPALMEROS2017.pdf

MPOB (2017b). Malaysian Oil Palm Genome Programme (MyOPGP). http:// genomsawit. mpob.gov.my/

MURPHY, DJ (2007). Plant Breeding and Biotechnology: Societal Context and the Future of Agriculture. Cambridge University Press, Cambridge, UK.
MURPHY, D (2014). The future of oil palm as a major global crop: opportunities and challenges. J. Oil Palm Res.Vol. 26: 1-24.

MUSA, B and GURMIT, S (2008). Utilization of MPOB germplasm at UPB. Proc. of the $3^{\text {rd }}$ Seminar on Performance of MPOB PS1 and PS2 Materials and Elite Germplasm. MPOB, Bangi. p. 43-72.

NASA (2017). National Aeronautics and Space Administration. https: / / www.nasa.gov

NIZAM, M S; CHE RADZIAH, C M Z; WAN JULIANA, W A and FATHURRAHMAN (2015). Effects of elevated concentration of carbon dioxide $\left(\mathrm{CO}_{2}\right)$ on growth of oil palm seedlings (Elaeis guineensis Jacq.). International Seminar on Gearing Oil Palm Breeding and Agronomy for Climate Change. Kuala Lumpur, Malaysia. p. 25.

NOH, A; RAJANAIDU, N; KUSHAIRI, A; MOHD RAFII, Y; MOHD DIN, A; MOHD ISA, Z A and SALEH, G (2002). Variability in fatty acid composition, iodine value and carotene content in the MPOB oil palm germplasm collection from Angola. J. Oil Palm Res.Vol. 14: 18-23.

$\mathrm{NOH}, \mathrm{A}$; KUSHAIRI, A; MOHD DIN, A; MAIZURA, I; ISA, Z A and RAJANAIDU, N (2005). PS10: Breeding populations selected for long stalk. $M P O B$ Information Series No. 263. MPOB, Bangi.

NOH, A; RAJANAIDU, N; KUSHAIRI, A; MOHD DIN, A and WAN NOORAIDA, W M (2014). PS 14: Oil palm breeding population selected for high protein kernel. MPOB Information Series No. 566. MPOB, Bangi.

NORZIHA, A; MARHALIL, M; FADILA, A.M; MOHD DIN, A; NOH, A and RAJANAIDU, N (2015). Studies of the germination rate of Elaeis oleifera using various methods. Proc. of the International Conference on Crop Improvement. UPM Serdang, Selangor, Malaysia.

NORZIHA, A; FADILA, A M; MARHALIL, M; ZULKIFLI, Y.; MOHD DIN, A; RAJANAIDU, N and KUSHAIRI, A (2017). Evaluation of MPOB oil palm (Elaeis guineensis Jacq.) germplasm for compact trait. $12^{\text {th }}$ Malaysia International Genetics Congress (MiGC12). Bangi-Putrajaya Hotel, Selangor, Malaysia.

NUZUL, H D (2015). Agricultural practice strategies in oil palm plantation to adapt climate change. Proc. of the International Seminar on Gearing Oil Palm Breeding and Agronomy for Climate Change. Kuala Lumpur, Malaysia. p. 9-14.

OIL WORLD (2016). Oil World Annual. ISTA Mielke GmbH. https: / / www.oilworld.biz / 
OKOYE, M N; BAKOUMÉ, C; UGURU, M I; SINGH, R and OKWUAGWU, C O (2016). Genetic relationships between elite oil palms from Nigeria and selected breeding and germplasm materials from Malaysia via simple sequence repeat (SSR) markers. J Agri Sci, 8(2).

ONG-ABDULLAH, M; ORDWAY, J M; JIANG, N; OOI, S-E; KOK, S-Y; SARPAN, N; AZIMI, N; HASHIM, A T; ISHAK, Z; ROSLI, S K; MALIKE, F A; BAKAR, N A A; MARJUNI, M; ABDULLAH, $\mathrm{N}$; YAAKUB, Z; AMIRUDDIN, M D; NOOKIAH, R; SINGH, R; LOW, E-T L; CHAN, K-L; AZIZI, N; SMITH, S W; BACHER, B; BUDIMAN, M A; VAN BRUNT, A; WISCHMEYER, C; BEIL, M; HOGAN, $\mathrm{M}$; LAKEY, N; LIM, C-C; ARULANDOO, X; WONG, C-K; CHOO, C-N; WONG, W-C; KWAN, Y-Y; ALWEE, S S R S; SAMBANTHAMURTHI, R and MARTIENSSEN, R A (2015). Loss of Karma transposon methylation underlies the mantled somaclonal variant of oil palm. Nature, 525: 533-537.

ONG-ABDULLAH, M; ORDWAY, J M; JIANG, N; OOI, S-E; MOKRI, A; KOK, S Y; SARPAN, N; AZIMI, N; HASHIM, A T; ISHAK, Z; ROSLI, S K; NOOKIAH, R; SINGH, R; LOW, E-T L; SACHDEVA, M; SMITH, S W; LAKEY, N; MARTIENSSEN, R A and SAMBANTHAMURTHI, R (2016). Tissue culture and epigenetics. The Planter, 92: 741-749.

PALAT, T; CHAYAWAT, $\mathrm{N}$ and CORLEY, R H V (2012). Maximising oil palm yield by high density planting and thinning. The Planter, 88: 241- 256.

POOTAKHAM, W; JOMCHAI, N; RUANGAREERATE, P; SHEARMAN, J R; SONTHIROD, C; SANGSRAKU, D; TRAGOONRUNG, $\mathrm{S}$ and TANGPHATSORNRUANG， S (2015). Genomewide SNP discovery and identification of QTL associated with agronomic traits in oil palm using genotyping-by-sequencing (GBS). Genomics, 105(56): 288-295.

RAJANAIDU, N (1986). The oil palm (Elaeis guineensis) collections in Africa. Proc. of the International Workshop on Oil Palm Germplasm and Utilisation. PORIM, Bangi. p. 59-83.

RAJANAIDU, N and RAO, V (1987). Oil palm genetic collections: their performance and use to the industry. Proc. of the International Oil Conference in Agriculture. Kuala Lumpur, Malaysia. p. 59-85.

RAJANAIDU, N (1994). PORIM Oil Palm Genebank. PORIM, Bangi.p. 19.

RAJANAIDU, N; KUSHIARI, A and JALANI, B S (1999). Systems approach to the management of oil palm breeding and biotechnology. Proc. of the 1999
PORIM International Palm Oil Congress (PIPOC) (Ariffin Darus; Chan K W and Sharifah, S R S A eds.). PORIM, Bangi. p. 79-89.

RAJANAIDU, N; KUSHAIRI, A; RAFII, M; MOHD DIN, A; MAIZURA, I and JALANI, B S (2000). Oil palm breeding and genetic resources. Advances in Oil Palm Research (Yusof, B; Jalani, B S and Chan, K W eds.). MPOB, Bangi, Selangor. p. 171-237.

RAJANAIDU, N; KUSHAIRI, A; MOHD DIN, A; MARHALIL, M; FADILA, A M and ISA, Z A (2011). Selection criteria (15-15-15) to develop sustainable oil palm planting materials. Proc. of the International Seminar on Breeding for Sustainability in Oil Palm. Kuala Lumpur, Malaysia. p. 112.

RAJANAIDU, N; AINUL, M M; KUSHAIRI, A and MOHD DIN, A (2013). Historical review of oil palm breeding for the past 50 years - Malaysian journey. Proc. of the International Seminar on Oil Palm Breeding - Yesterday, Today and Tomorrow, Kuala Lumpur, Malaysia. p. 11-28.

RAJINDER, S; JAYANTHI, N; SOON-GUAN, T; JOTHI, M P and CHEAH, S C (2007). Development of simple sequence repeat (SSR) markers for oil palm and their application in genetic mapping and fingerprinting of tissue culture clones. AsPac J. Mol. Biol. Biotechnol., 15 (3): 121-131.

RANCE, K A; MAYES, S; PRICE, Z; JACK, P L and CORLEY, R H V (2001). Quantitative trait loci for yield components in oil palm (Elaeis guineensis Jacq.). Theor Appl Genet, 103(8): 1302-1310.

ROHANI, O; SHARIFAH, S A; MOHD RAFII, Y; ONG, M; TARMIZI, A H and ZAMZURI, I (2000). Tissue culture of oil palm. Chapter 7. Advances in Oil Palm Research (Yusof, B; Jalani, B S and Chan, K W, eds.). Volume 1. MPOB, Bangi. p. 238-283.

ROSLAN, A and IDRIS, A (2012). Economic impact of Ganoderma incidence on Malaysian oil palm plantation - a case study in Johor. Oil Palm Industry Economic Journal Vol. 12: 24-30.

ROSLI, R; AB HALIM, M A; CHAN, K L; AZIZI, $\mathrm{N}$; JAYANTI, N; NIK MOHD SANUSI, N S; AMIRUDIN, N ; ABDUL RAZAK, A S; KADRI, F and LOW, E T L (2014). MPOB Information Series No. 134. MPOB, Bangi.

SAKHANOKHO, H F and KELLEY, R Y (2009). Influence of salicylic acid on in vitro propagation and salt tolerance in Hibiscus acetosella and Hibiscus moscheutos (cv Luna Red). Afr. J. Biotechnol. 8: 14741481. 
SATTAR, M N; IQBAL, Z; TAHIR, M N; SHAHID, M S; KHURSHID, M; AL-KHATEEB, A A and AL KATEEB, S A (2017). RISPR/Cas9: A practical approach in date palm genome editing. Front Plant Sci, 8: 1469. DOI: 10.3389/fpls.2017.01469.

SCHULTES, R E (1990). Taxonomic nomenclature and ethnobotanic notes on Elaeis. Elaeis, 2: 172-187.

SHAMALA, S (2013). The effects of Trichoderma in surface mulches supplemented with conidial drenches in the disease development of Ganoderma basal stem rot in oil palm. J. Oil Palm Res.Vol. 25: 314-25.

SINGH, R; TAN S G; PANANDAM, J M; RAHMAN, R A; OOI, L C; LOW, E T L; SHARMA, M; JANSEN, J and CHEAH, S C (2009). Mapping quantitative trait loci (QTLs) for fatty acid composition in an interspecific cross of oil palm. BMC Plant Biol, 9: 114. DOI: 10.1186/1471-2229-9-114.

SINGH, R; MEILINA, O-A; LOW, E-T L; ABDUL MANAF, M A; ROSLI, R; RAJANAIDU, N; OOI, L C L; OOI, S E; CHAN, K L; HALIM, M A; AZIZI, $\mathrm{N}$; NAGAPPAN, J; BACHER, B; LAKEY, N; SMITH, S W; H E, D; HOGAN, M; BUDIMAN, M A; LEE, E K; DE SALLE, R; KUDRNA, D; GOICOECHEA, J L; WING, R A; WILSON, R K; FULTON, R S; ORDWAY, J M; MARTIENSSEN, R A and SAMBANTHAMURTHI, R (2013a). Oil palm genome sequence reveals divergence of interfertile species in Old and New worlds. Nature, 500: 335339.

SINGH, R; LOW, E-T L; MEILINA, O-A; RAJANAIDU, N; TING, N C; MARJUNI, M; CHAN, P L; MAIZURA, I; ABDUL MANAF, M A; NAGAPPAN, J; CHAN, K L; ROSLI, R; HALIM, M A; AZIZI, N; BUDIMAN, M A; LAKEY, N; BACHER, B; BRUNT A V; MARTIENSSEN, R A and SAMBANTHAMURTHI, R (2013b). The oil palm VIRESCENS gene controls fruit colour and encodes a R2R3-MYB. Nature Comm, 4106. DOI:10.1038/ ncomms5106.

SIRIM (2008). Malaysian Standard MS2099: 2008. Oil Palm Clones for Commercial Planting Specification for Ortet Selection. Department of Standards, Malaysia.

SITI HAWA, M S; TZER, Y S; NURUL HAFIZAH, R; LING-JIUN, L; MOHD LATIF, K; RAO, V and SHARIFAH SHAHRUL RABIAH, S A (2015). DNA fingerprinting of FGV elite Yangambi breeding materials. Proc. of the $2^{\text {nd }}$ International Conference on Crop Improvement (ICCI). p. 84.
SPRINGER, N M and SCHMITZ, R J (2017). Exploiting induced and natural epigenetic variation for crop improvement. Nat Rev Genet, 18: 563-75.

SOH, A C; MAYES, S and ROBERTS, J A (2017). Oil Palm Breeding: Genetics and Genomics. CRC Press, US.

SOTO-CERDA, B J and CLOUTIER, S (2012). Association mapping in plant genomes. Genetic Diversity in Plants (Caliskan, M ed.). InTech.

SUHAILY, S S; JAWAID, M; ABDUL KHALIL, H P S and IBRAHIM, F (2012). A review of oil palm biocomposites for furniture design and applications: potential and challenges. BioResour, 7: 4400-4423.

SUTHASHINIKISAN, K (2015). Fine tuning of the Nigerian germplasm breeding programme at FGV for climate change in Malaysia. Proc. of the International Seminar on Gearing Oil Palm Breeding and Agronomy for Climate Change. Kuala Lumpur, Malaysia. p. 8.

TAN, C C; WONG, G; SOH, A C; HOR, T Y; CHONG, S P and GOPAL, K (2003). Experience and lessons from oil palm clonal evaluation trials and commercials test planting. AAR Tech Reprt No 6/03.

TEH, C K; ONG, A L; KWONG, Q B; APPAROW, S; CHEW, F K; MAYES, S; MOHAMED, M; APPLETON, D and KULAVEERASINGAM, H (2016). Genome-wide association study identifies three key loci for high mesocarp oil content in perennial crop oil palm. Sci Rep, 6: 19075.

TESTER, M and LANGRIDGE, P (2010). Breeding technologies to increase crop production in a changing world. Science, 327: 818-822.

TING, N C; JANSEN, J; MAYES, S; MASSAWE, F; SAMBANTHAMURTHI, R and OOI, L C (2014). High density SNP and SSR-based genetic maps of two independent oil palm hybrids. BMC Genomics, 15: 309 .

TING, N C; ZULKIFLI, Y; KATIALISA, K; MAYES, S; MASSAWE, F; SAMBANTHAMURTHI, R; JANSEN, J; LOW, E T L; MAIZURA, I; KUSHAIRI, A; ARULANDOO, X; ROSLI, R; NADZIRAH, A; SRITHARAN, K; LIM, C C L; RAJANAIDU, N and MOHD DIN, A (2016). Fine-mapping and crossvalidation of QTLs linked to fatty acid composition in multiple independent interspecific crosses of oil palm. BMC Genomics, 17: 289.

USDA (2017). World production, market and trade reports. https: / / www.fas.usda.gov / data/ oilseedsworld-markets-and-trade 
VIGNAL, A; MILAN, D M; SANCRISTOBAL, M; and EGGEN, A (2002). A review on SNP and other types of molecular markers and their use in animal genetics. Genet Sel Evol, 34: 275-305.

WAN IBRAHIM, W H; ZULKIFLI, Y; NORZIHA, A; ROSIMAH, N and MARIA, M (2011). Obtaining oil palm haploids via screening for naturally occurring haploid $(\mathrm{NOH})$ in oil palm germinated seeds and wide hybridization. Proc. of the PIPOC International Palm Oil Congress. KLCC, Kuala Lumpur, Malaysia.

WOITTIEZ, L S; VAN WIJK, M T; SLINGERLAND, M; VAN NOORWIJK, M and GILLER, K E (2017). Yield gaps in oil palm: a quantitative review of contributing factors. Europ. J. Agronomy, 83: 57-77.

WONG, C K and BERNARDO, R (2008). Genomewide selection in oil palm: increasing selection gain per unit time and cost with small populations. Theor Appl Genet, 116(6): 815-824.
ZAMZURI, I (2011). MPOB clonal propagation programme. International Seminar on Breeding for Sustainability in Oil Palm. Kuala Lumpur, Malaysia.

ZAKI, N M; SINGH, R; ROSLI, $\mathrm{R}$ and ISMAIL, I (2012). Elaeis oleifera genomic-SSR markers: exploitation in oil palm germplasm diversity and cross-amplification in Arecaceae. Intl J Mol Sci, 13(4): 4069-4088.

ZULKIFLI, Y; MAIZURA, I and RAJINDER, S (2012). Evaluation of MPOB oil palm germplasm (Elaeis guineensis) populations using EST- SSR. J. Oil Palm Res.Vol. 24: 1368-1377.

ZULKIFLI, Y; RAJINDER, S; MOHD DIN, A; TING, N C; RAJANAIDU, N; KUSHAIRI, A and ISMANIZAN, I (2014). Inheritance of SSR and SNP loci in an oil palm interspecific hybrid backcross (BC2) population. J. Oil Palm Res. Vol. 26(3): 203-213.

\section{Early View}

Beginning October 2017, Early View is available in JOPR Microsite.

Articles which have been accepted for publication, edited and checked by authors are published online as Early View in Articles in Press section in the JOPR Microsite before the final online and print version of JOPR is published. Early View (also known as online first by other journals) articles although do not yet have page No. and volume/issue details but has been assigned to a Digital Object Identifier (DOI) No. for tracking and citations purposes. This is to accelerate the publication and dissemination of the latest research output.

To view all the articles currently available in Early View, visit http: / / jopr.mpob.gov.my / ?mycat=InPress 